\title{
Clinical Presentation and Outcomes of Hospitalized Children with COVID-19 in Mexico City
}

\author{
David Diaz ${ }^{1}$, Samuel Urrutia ${ }^{2}$, Gabriel Gutierrez ${ }^{3}$, and Francisco Cuevas ${ }^{3}$ \\ ${ }^{1}$ Instituto Nacional de Pediatría \\ ${ }^{2}$ The University of Texas MD Anderson Cancer Center \\ ${ }^{3}$ Instituto Nacional de Pediatria
}

February 11, 2022

\begin{abstract}
We describe the demographic, clinical, radiological and laboratory findings relating them also to the severity and clinical outcome of 129 children (0-18 years) which were admitted to a tertiary care pediatric hospital in Mexico City due to SARSCoV-2 infection between April 1, 2020, to March 31, 2021. The infection was confirmed using RT-PCR. Fever (82.2\%), tachypnea $(72.1 \%)$ and cough $(71.3 \%)$ were the most commonly reported signs at the moment of hospitalization. The most frequent radiological pattern that stood out was the interstitial pattern (66.7\%). History of oncologic pathology (25.6\%) was the most frequent past medical history. ESR (erythrocyte sedimentation rate) was the only laboratory value significantly associated with severity $(\mathrm{p}=0.015)$. NSAIDs $(93 \%)$, antibiotics $(57.4 \%)$, and steroids $(40.3 \%)$ were the most common medication given. The average hospitalization stay was 14.2 days, $21.7 \%$ of the total patients required transfer to the intensive care unit. At discharge, $20.2 \%$ required oxygen on an outpatient basis, and unfortunately $7.0 \%$ of the patients who were admitted to the institute for COVID-19 died. Our findings confirm that COVID-19 in children has a mild presentation except for patients with hematologic/oncologic co-morbidities which had severe presentations.
\end{abstract}

\section{Hosted file}

Title Page 2.0.docx available at https://authorea.com/users/460078/articles/556149-clinicalpresentation-and-outcomes-of-hospitalized-children-with-covid-19-in-mexico-city

\section{Hosted file}

Final Version 2ndA.docx available at https://authorea.com/users/460078/articles/556149clinical-presentation-and-outcomes-of-hospitalized-children-with-covid-19-in-mexico-city

\section{Hosted file}

Tables Final.docx available at https://authorea.com/users/460078/articles/556149-clinicalpresentation-and-outcomes-of-hospitalized-children-with-covid-19-in-mexico-city 